\title{
Kualitas Rencana Pelaksanaan Pembelajaran (RPP) dan Implementasinya dalam Pembelajaran Matematika SMA
}

\author{
Ihdi Amin ${ }^{1 *}$, YL. Sukestiyarno ${ }^{2}$, St. Budi Waluya ${ }^{3}$, Scolastika Mariani ${ }^{4}$ \\ 1,2,3,4Program Doktoral Pendidikan Matematika, Universitas Negeri Semarang; \\ 1,*ihdimathsma@yahoo.com; 2sukestiyarno@gmail.com; 3budiwmathunnes@yahoo.com; \\ ${ }^{4}$ scmariani.unnes@gmail.com
}

Info Artikel: Dikirim: 10 Desember 2019; Direvisi: 15 Januari 2020; Diterima: 21 Februari 2020 Cara sitasi: Amin, I., Sukertiyarno, YL., Waluya, B. S., \& Mariani, S. (2020). Kualitas Rencana Pelaksanaan Pembelajaran (RPP) dan Implementasinya dalam Pembelajaran Matematika SMA. JNPM (Jurnal Nasional Pendidikan Matematika), 4(1), 125-141.

\begin{abstract}
Abstrak. Rencana Pelaksanaan Pembelajaran (RPP) merupakan deskripsi tertulis tentang rencana kegiatan pembelajaran yang seharusnya dapat diimplementasikan dalam praktik pembelajaran. Penelitian ini bertujuan menganalisis kualitas RPP dan implementasinya dalam pembelajaran matematika SMA. Penelitian dilakukan secara kualititatif. Subjek penelitian meliputi 32 orang guru matematika SMA. Analisis data digunakan metode triangulasi (membandingkan data observasi, kuesioner, dan wawancara terbatas). Hasil menunjukkan bahwa kualitas RPP berada pada kategori cukup di semua indikator, sedangkan implementasinya berada pada kategori cukup hanya pada indikator perumusan materi ajar dan kegiatan pembelajaran, pada indikator yang lain berada pada kategori kurang. Dalam hal ini guru matematika SMA disarankan dapat mengembangkan RPP yang lebih berkualitas dan implementatif, yang mampu membiasakan siswa pada kegiatan pemecahan masalah, pengembangan HOTs dan kinerja metakognitif, serta melakukan kegiatan evaluasi yang komprehensif.
\end{abstract}

Kata kunci: Rencana Pelaksanaan Pembelajaran (RPP), Implementasi RPP, Pembelajaran Matematika.

\begin{abstract}
The lesson plan is a written description of the program of learning activities that can be implemented in learning practices. This study aimed to analyze the quality of lesson plans and their implementation in high school mathematics learning. Research subjects included 32 high school mathematics teachers selected. Data analysis used triangulation methods (comparing observational data, questionnaires, and limited interviews). The results of the triangulation shown that the quality of lesson plans was in the adequate category in all indicators, while its implementation was in the sufficient category only in the indicators of the formulation of teaching materials and learning activities. In other indicators, it was in the inadequate category. Mathematics teachers in secondary schools were advised to develop the lesson plan, which more quality and implementation, which were able to familiarize students with problem-solving activities, improve HOT skill and metacognitive performance, and conduct of evaluation process, which more comprehensive.
\end{abstract}


Keywords: Lesson Plan, Implementation of Lesson Plan, Mathematics Learning.

\section{Pendahuluan}

Reformasi kurikulum pada awal abad ke-21 telah banyak mengalami perubahan dalam isi kurikulum, metode pengajaran, edisi buku teks, dan metode penilaian (Wang, Liu, Du, \& Liu, 2017). Selanjutnya pada era globalisasi ini kita dituntut mampu melakukan: kerja dalam tim, komunikasi yang efektif, pengambilan keputusan bersama, berbagi informasi, memanfaatkan teknologi informasi, dan inovasi (Habib, 2017). Ini menjadi salah satu alasan yang melatarbelakangi pengembangan Kurikulum 2013.

Kurikulum 2013 dirancang untuk mempersiapkan orang Indonesia sebagai warga negara, yang memiliki keyakinan, yang produktif, kreatif, inovatif dan efektif serta mampu berkontribusi pada masyarakat, bangsa, negara, dan peradaban dunia (Jaedun, Hariyanto, \& Nuryadin, 2014). Pemberlakuan kurikulum 2013 mengharuskan adanya perubahan paradigm pembelajaran, dari teacher center menjadi student center. Untuk mengubah paradigma tersebut, guru dituntut mampu membuat perencanaan pengajaran untuk berbagai tingkat kemampuan, berbagai pengalaman bahasa, dan berbagai pengetahuan budaya dan bahasa (Holmes \& Holmes, 2011), sehingga guru dapat berpartisipasi dalam proses pengembangan kurikulum (Mosothwanei, 2012).

Selama ini investasi dalam pengembangan profesioalitas guru dirasa masih kurang termasuk di Indonesia (Ejiwale, 2013). Sosialisasi Kurikulum 2013 belum menjangkau secara menyeluruh pada semua guru dan siswa (Rumahlatu, Huliselana, \& Takariaa, 2016), sehingga masih banyak guru yang belum memahami proses pembelajaran dan penilaian sesuai dengan tuntutan Kurikulum 2013 (Kuncara, Sujadi, \& Riyadi, 2016). Oleh karena itu dibutuhkan sosialisasi dan pelatihan yang lebih intens agar para guru dapat menyusun RPP dan melaksanakan kegiatan pembelajaran yang sesuai dengan harapan kurikulum 2013.

Sebagian besar teori pembelajaran memiliki prinsip-prinsip pengajaran diantaranya siswa berproses melalui tahapan-tahapan, dan materi harus diorganisir dan disajikan dalam langkah-langkah kecil (Schunk, 2012). Untuk menciptakan pembelajaran yang efektif diperlukan persiapan kontens materi yang akan dibahas, pertimbangan metode pengajaran dan pengalaman belajar, dan proses penilaian yang direncanakan (John, 2006). Hal tersebut 
selanjutnya dituangkan dalam suatu rencana pengajaran atau rencana pelaksanaan pembelajaran (RPP).

Perencanaan pengajaran adalah peta atau kerangka kerja yang digunakan untuk merencanakan dan mengarahkan setiap kelas (Shrawder, 2006). Rencana pembelajaran merupakan deskripsi tertulis dari proses pendidikan di mana diperlihatkan apa, kapan, di mana dan dengan metode apa peserta harus belajar dan bagaimana mereka harus dinilai (Nesari \& Heidari, 2014), Perencanaan pembelajaran yang baik menggambarkan bagaimana guru akan menjangkau tujuan pembelajaran (Shrawder, 2006) dan memungkinkan siswa menjadi pembelajar yang sukses (Duncan \& Met, 2010).

Rencana pembelajaran merupakan produk penting dari kegiatan pembelajaran dimana guru memiliki wewenang untuk merumuskan pernyataan mereka (Latifa, 2017) dan mengeksplorasi berbagai aspek pengetahuan konten pedagogis (Shen, Poppink, Cui, \& Fan, 2007), sehingga menjadi bagian penting dan integral dari kegiatan pengajaran yang kompleks (Zazkis, Liljedahl, \& Sinclair, 2009). Pada akhirnya, rencana pembelajaran dapat menjadi ciri profesionalisme guru (Jones, 1998).

Menurut Cicek (2013), perencanaan pembelajaran yang dibuat guru meliputi: (1) rencana tahunan; (2) rencana pelajaran harian; dan (3) rencana pengganti guru. Komponen pengembangan rencana pembelajaran (RPP) pada Kurikulum 2013 mencakup enam aspek: (1) perumusan indicator dan tujuan pembelajaran, (2) perumusan materi pelajaran, (3) sumber dan media pembelajaran, (4) metode/model/pendekatan pembelajaran, (5) kegiatan pembelajaran, dan (6) evaluasi pembelajaran.

Perumusan indikator berkaitan langsung dengan tujuan pembelajaran yang ingin dicapai. Menuru Tyler (John, 2006), tujuan akan dapat dicapai apabila ditetapkan dengan jelas sebagai bagian yang paling penting dari kegiatan pembelajaran. Tujuan pembelajaran juga dapat dicapai dengan lebih efektif jika disiapkan media pembelajaran yang tepat. Media pembelajaran berarti sarana yang digunakan sebagai pelantara dalam membawa pesan pembelajaran (Daryanto, 2010).

Selain faktor pemilihan media dan sumber pembelajaran, efektivitas pembelajaran juga ditentukan oleh kemampuan guru dalam merancang kegiatan pembelajaran. Menurut Muijs \& Reynolds (2008) pengajaran langsung yang efektif akan dapat dicapai diantaranya melalui pengajaran dan penyajian materi yang distrukturisasikan dengan jelas. 
Pada akhir kegiatan pembelajaran, perlu dilakukan proses penilaian pembelajaran. Melakukan proses penilaian pembelajaran perlu memperhatikan beberapa hal, yaitu: (1) mengukur tingkat berpikir siswa mulai dari rendah sampai tinggi, (2) menekankan pada pertanyaan yang membutuhkan pemikiran mendalam (bukan sekedar hafalan), (3) mengukur proses kerjasama, bukan hanya hasil kerja, dan (4) menggunakan portofolio pembelajaran siswa (Kemdikbud, 2016).

Keseluruhan penjelasan di atas meneguhkan argumen bahwa guru perlu menyadari pentingnya merancang RPP. Guru dituntut mampu membuat RPP yang berkualitas, yaitu RPP yang memiliki tujuan yang terukur, kegiatan yang diatur secara berurutan dengan baik, media yang praktis, efektif, dan sesuai, dan penilaian yang mengakomodasi perspektif pembelajaran yang berpusat pada siswa (Sesiorina, 2014).

Penelitian ini bertujuan menganalisis kualitas RPP mata pelajaran Matematika SMA dan implementasinya dalam praktik kegiatan pembelajaran. Rumusan masalah yang ingin dijawab melalui penelitian ini adalah (1) bagaimana kualitas rumusan RPP yang telah dikembangkan oleh guru matematika SMA?; (2) bagaimana implementasi RPP dalam praktik kegiatan pembelajaran di kelas?.

\section{Metode}

Metode penelitian adalah kualitatif. Ruang lingkup penelitian ini adalah aktivitas guru matematika SMA dalam kegiatan pembelajaran dikaitkan dengan RPP yang dibuatnya, sehingga subyek penelitian yang diambil pada penelitian ini adalah 32 orang guru matematika SMA se-Kabupaten Brebes. Variabel yang diukur dalam penelitian ini ada dua jenis, yaitu kualitas produk RPP yang dikembangkan guru dan kualitas implementasi RPP dalam kegiatan pembelajaran matematika. Data kualitas RPP diambil melalui observasi produk RPP menggunakan instrumen observasi RPP sedangkan data implementasi RPP diambil menggunakan kuesioner keterlaksanaan pembelajaran (KKP) dan kegiatan wawancara terbatas (hanya pada beberapa guru) yang merepresentasikan produk RPP hasil observasi dengan kategori baik, cukup baik, dan kurang baik

Data dianalisis dengan metode triangulasi yakni dengan membandingkan informasi atau data yang diperoleh melalui observasi, kuesioner, dan wawancara terbatas. Kriteria hasil observasi kualitas RPP dan kuesioner implementasi RPP berkaitan dengan skor yang dihasilkan ditetapkan sebagai 
berikut: (1) kurang, untuk skor $<2,5$; (2) cukup, untuk 2,5 $\leq$ skor $<3,5$; dan (3) baik, untuk skor $\geq 3,5$.. Penjabaran indikator dapat dilihat pada Tabel 1.

Tabel 1. Indikator Pembelajaran pada Implementasi Kurikulum 2013

\begin{tabular}{|c|c|c|c|}
\hline No. & Indikator & & Deskripsi \\
\hline \multirow[t]{3}{*}{1.} & Perumusan & 1.1 & Sesuai dengan kompetensi dasar yang diinginkan \\
\hline & indicator & 1.2 & Menggunakan kata kerja operasional yang dapat diukur \\
\hline & & 1.3 & $\begin{array}{l}\text { Memuat level kemampuan berpikir tingkat tinggi (hots) } \\
\text { dan/atau problem solving }\end{array}$ \\
\hline \multirow[t]{3}{*}{2.} & Perumusan & 2.1 & Sesuai dengan indikator yang dikembangkan \\
\hline & materi pelajaran & 2.2 & Sesuai dengan perkembangan dan kemampuan siswa \\
\hline & & 2.3 & $\begin{array}{l}\text { Memuat hal-hal yang berkaitan dengan dunia nyata } \\
\text { (kehidupan sehari-hari) }\end{array}$ \\
\hline \multirow[t]{3}{*}{3.} & Sumber dan & 3.1 & Memudahkan siswa menguasai materi \\
\hline & media & 3.2 & Memanfaatkan beberapa sumber belajar yang relevan \\
\hline & pembelajaran & 3.3 & $\begin{array}{l}\text { Memberdayakan teknologi informatika dan komunikasi } \\
\text { (tik) }\end{array}$ \\
\hline \multirow[t]{4}{*}{4.} & Metode, & 4.1 & Mengembangkan kreativitas berpikir siswa \\
\hline & $\begin{array}{l}\text { model,dan } \\
\text { pendekatan }\end{array}$ & 4.2 & $\begin{array}{l}\text { Meningkatkan partisipasi siswa dalam pembelajaran } \\
\text { (siswa lebih aktif) }\end{array}$ \\
\hline & pembelajaran & 4.3 & Mengembangkan kemampuan pemecahan masalah \\
\hline & & 4.4 & $\begin{array}{l}\text { Mengembangkan kemampuan metakognitif (control/ } \\
\text { refleksi belajar) }\end{array}$ \\
\hline \multirow[t]{3}{*}{5.} & $\begin{array}{l}\text { Kegiatan } \\
\text { pembelajaran }\end{array}$ & 5.1 & $\begin{array}{l}\text { Kegiatan pendahuluan, inti, dan penutup yang telah } \\
\text { terjabar dengan jelas }\end{array}$ \\
\hline & & 5.2 & $\begin{array}{l}\text { Penerapan metode/model/pendekatan pembelajaran } \\
\text { pada kegiatan inti }\end{array}$ \\
\hline & & 5.3 & Penerapan kegiatan saintifik \\
\hline \multirow[t]{3}{*}{6.} & $\begin{array}{l}\text { Evaluasi } \\
\text { pembelajaran }\end{array}$ & 6.1 & $\begin{array}{l}\text { Memunculkan instrument penilaian yang sesuai dengan } \\
\text { indikator yang dikembangkan }\end{array}$ \\
\hline & & 6.2 & Memunculkan penilian proses pembelajaran \\
\hline & & 6.3 & Memiliki pedoman penskoran \\
\hline
\end{tabular}

\section{Hasil dan Pembahasan}

Rekap data observasi produk RPP berdasarkan indikator pembelajaran pada implementasi kurikulum 2013 ditampilkan pada Tabel 2. Data pada Tabel 2 menunjukkan bahwa kualitas RPP yang disusun guru masih berada pada kriteria cukup di seluruh indikator penilaian RPP.

Dari enam indikator yang diukur, rumusan materi pelajaran menunjukkan kualitas yang paling rendah, sedangkan kegiatan pembelajaran menunjukkan kualitas paling tinggi. 
Tabel 2. Rekap Data Observasi Produk RPP

\begin{tabular}{|c|c|c|c|c|c|c|c|c|c|}
\hline \multirow{2}{*}{ No. } & \multirow{2}{*}{ Indikator } & \multirow{2}{*}{ Nilai } & \multicolumn{5}{|c|}{ Sub Indikator } & \multirow{2}{*}{ Total } & \multirow{2}{*}{ Krteria } \\
\hline & & & 1 & 2 & 3 & 4 & 5 & & \\
\hline \multirow[t]{2}{*}{1.} & Perumusan indicator & $\bar{x}$ & 4.00 & 3.89 & 1.26 & & & 3.05 & Cukup \\
\hline & & $S D$ & 0.00 & 0.37 & 1.00 & & & 0.40 & \\
\hline \multirow[t]{2}{*}{2.} & Perumusan materi & $\bar{x}$ & 4.00 & 2.67 & 1.59 & & & 2.75 & Cukup \\
\hline & pelajaran & $S D$ & 0.00 & 0.84 & 0.67 & & & 0.44 & \\
\hline \multirow[t]{2}{*}{3.} & Sumber dan media & $\bar{x}$ & 3.33 & 3.96 & 2.07 & & & 3.12 & Cukup \\
\hline & pembelajaran & $S D$ & 0.54 & 0.25 & 0.76 & & & 0.37 & \\
\hline \multirow[t]{2}{*}{4.} & Metode, model,dan & $\bar{x}$ & 3.89 & 3.89 & 2.41 & 1.56 & & 2.94 & Cukup \\
\hline & $\begin{array}{l}\text { pendekatan } \\
\text { pembelajaran }\end{array}$ & $S D$ & 0.34 & 0.37 & 0.60 & 0.51 & & 0.33 & \\
\hline \multirow[t]{2}{*}{5.} & Kegiatan & $\bar{x}$ & 3.78 & 3.85 & 3.78 & 2.00 & 3.78 & 3.44 & Cukup \\
\hline & pembelajaran & $S D$ & 0.44 & 0.34 & 0.44 & 0.90 & 0.44 & 0.35 & \\
\hline \multirow[t]{2}{*}{6.} & Evaluasi & $\bar{x}$ & 3.93 & 3.11 & 2.81 & & & 3.28 & Cukup \\
\hline & pembelajaran & $S D$ & 0.30 & 0.62 & 0.98 & & & 0.49 & \\
\hline
\end{tabular}

Rekap data kuesioner tentang implementasi rencana pengajaran dalam proses pembelajaran matematika dapat dilihat pada Tabel 3.

Tabel 3. Rekap Data Kuesioner Implementasi Rencana Pengajaran dalam Proses Pembelajaran Matematika SMA (variabel X.2) X.2)

\begin{tabular}{|c|c|c|c|c|c|c|c|c|c|}
\hline & \multirow{2}{*}{ Indikator } & \multirow{2}{*}{ Nilai } & \multicolumn{5}{|c|}{ Sub Indikator } & \multirow{2}{*}{ Total } & \multirow{2}{*}{ Kriteria } \\
\hline & & & 1 & 2 & 3 & 4 & 5 & & \\
\hline \multirow[t]{2}{*}{1.} & Perumusan & $\bar{x}$ & 3.41 & 2.26 & 1.70 & & & 2.46 & Kurang \\
\hline & indikator & $S D$ & 0.76 & 0.86 & 0.95 & & & 0.69 & \\
\hline \multirow[t]{2}{*}{2.} & Perumusan & $\bar{x}$ & 3.00 & 2.85 & 2.00 & & & 2.62 & Cukup \\
\hline & materi pelajaran & $S D$ & 0.84 & 0.87 & 0.89 & & & 0.65 & \\
\hline \multirow[t]{2}{*}{3.} & Sumber dan & $\bar{x}$ & 2.52 & 2.59 & 2.04 & & & 2.38 & Kurang \\
\hline & $\begin{array}{l}\text { media } \\
\text { pembelajaran }\end{array}$ & $S D$ & 0.91 & 0.62 & 0.64 & & & 0.51 & \\
\hline \multirow[t]{2}{*}{4.} & Metode/model $/ \mathrm{p}$ & $\bar{x}$ & 2.26 & 2.37 & 2.15 & 2.19 & & 2.24 & Kurang \\
\hline & $\begin{array}{l}\text { endekatan } \\
\text { pembelajaran }\end{array}$ & $S D$ & 0.77 & 0.98 & 0.93 & 0.91 & & 0.80 & \\
\hline \multirow[t]{2}{*}{5.} & Kegiatan & $\bar{x}$ & 2.96 & 2.89 & 2.59 & 2.00 & 2.26 & 2.54 & Cukup \\
\hline & pembelajaran & $S D$ & 0.74 & 0.82 & 0.66 & 0.90 & 0.74 & 0.61 & \\
\hline \multirow[t]{2}{*}{6.} & Evaluasi & $\bar{x}$ & 2.37 & 2.15 & 2.44 & & & 2.32 & Kurang \\
\hline & pembelajaran & $S D$ & 0.80 & 0.86 & 0.92 & & & 0.71 & \\
\hline
\end{tabular}

Data pada Tabel 3 menunjukkan bahwa implementasi RPP pada kriteria cukup hanya terjadi pada indikator perumusan materi pelajaran dan kegiatan pembelajaran, sedangkan pada indikator yang lain skor implementasi RPP berada pada kriteria kurang. 
Berkaitan dengan wawancara terbatas terhadap responden, hasil wawancara peneliti terhadap responden dengan kriteria baik dilihat dengan transkrip wawancara sebagai berikut.

$P$ (Peneliti) : Apakah Anda benar-benar melaksanakan pengukuran ketercapaian indikator?

$R$ (Responden) : Ya, diakhir pembelajaran saya selalu melaksanakan pengukuran ketercapaian indikator pembelajaran.

P: Apakah Anda mendorong siswa mencapai level berpikir tinggi (HOTS)/Problem solving

R: Ya, saya selalu berupaya kemampuan keterampilan HOTs dan pemecahan masalah

P: Apakah Anda dalam menyajikan materi selalu menyesuaikan dengan indicator yang dikembangkan?

R: Ya, saya selalu menjabarkan materi agar saya mudah dalam menjelaskan materi dan mencapai tujuan pembelajaran sesuai dengan indicator

P: Apakah Anda dalam menyajikan materi selalu menggunakan lebih dari satu sumber belajar yang relevan

R: Ya, saya selalu berupaya menggunakan beberapa sumber belajar yang relevan

P: Apakah Anda dalam menyajikan materi selalu menggunakan teknologi informatika dan komunikasi atau jaringan internet?

R: Ya, saya berupaya menyajikan materi berbasis IT agar kegiatan pembelajaran menjadi lebih menarik

P: Apakah Anda dalam menyajikan materi selalu menggunakan metode/model/pendekatan yang tertulis dalam RPP?

R: Ya, saya selalu berupaya menggunakan metode yang bervariasi, seperti yang tertulis dalam RPP, dan disesuaikan dengan karakteristik materi, sumber dan media yang tersedia, dan kerakteristik siswa.

P: Apakah kegiatan pembelajaran Anda laksanakan sesuai RPP yang dibuat?

R: Ya, saya selalu berupaya melaksanakan kegiatan pembelajaran dengan runtut dan jelas sesuai dengan RPP yang saya buat.

P: Apakah Anda selalu melaksanakan kegiatan saintifik/kegiatan pemecahan masalah?

$R$ : Ya, saya selalu mengupayakan kegiatan pemecahan masalah dan pembelajaran kolaboratif dalam setiap proses pembelajaran

P: Apakah Anda melakukan penilian proses pembelajaran (sesuai dengan yang tertulis dalam RPP)?

R: Ya, saya selalu melakukan penilaian yang dilakukan selama proses pembelajaran.

Hasil wawancara dengan kriteria baik berati terpenuhinya semua unsur pembelajaran sesuai dengan tuntutan Kurikulum 2013, yakni adanya pengukuran ketercapaian indikator pembelajaran, produk berpikir HOTs dan pemecahan masalah, menggunanakan berbagai sumber belajar, memanfaatkan TIK, pemilihan metode yang mendorong student center, dan penilaian yang komperhensif.

Transkrip wawancara terhadap responden dengan kriteria cukup dapat dilihat pada transkrip berikut.

P (Peneliti) : Apakah Anda benar-benar melaksanakan pengukuran ketercapaian indikator? 
$R$ (Responden) : Ya, diakhir pembelajaran saya cukup sering melaksanakan pengukuran ketercapaian indikator pembelajaran.

P: Apakah Anda mendorong siswa mencapai level berpikir tinggi (HOTS)/Problem solving

R: Hanya kadang-kadang saja menampilkan kemampuan keterampilan HOTs dan pemecahan masalah, dengan memperhatikan ketuntasan kuurikulum

P: Apakah Anda dalam menyajikan materi selalu menyesuaikan dengan indicator yang dikembangkan?

$R$ : Ya, tapi hanya menampilkan garis-garis besar materi dan sifat-sifat (teorema-teorema).

P: Apakah Anda dalam menyajikan materi selalu menggunakan lebih dari satu sumber belajar yang relevan

$R$ : Ya, saya selalu berupaya menggunakan beberapa sumber belajar yang relevan dan mudah digunakan siswa

P: Apakah Anda dalam menyajikan materi selalu menggunakan teknologi informatika dan komunikasi atau jaringan internet?

R: Tidak harus berbasis IT.

P: Apakah Anda dalam menyajikan materi selalu menggunakan metode/model/pendekatan yang tertulis dalam RPP?

R: Tidak selalu, penggunaan metode lebih ditekankan pada bagaimana siswa mudah memahami materi yang diberikan dan bagaimana mendorong partisipasi siswa

P: Apakah kegiatan pembelajaran Anda laksanakan sesuai RPP yang dibuat?

$R$ : Ya, saya laksanakan kegiatan pembelajaran secara runtut dari kegiatan pendahuluan, inti, dan penutup, pertimbangan alokasi waktu dan ketuntasan kurikulum.

P: Apakah Anda selalu melaksanakan kegiatan saintifik/kegiatan pemecahan masalah?

R: Tidak, kegiatan pemecahan masalah kolaboratif hanya sewaktu-waktu saja diberikan

P: Apakah Anda melakukan penilian proses pembelajaran sesuai dengan yang tertulis dalam RPP?

$R$ : Ya, tapi penilaian proses pada saat kegiatan kolaboratif dan pemecahan masalah saja, tidak sepanjang kegiatan pembelajaran.

Hasil wawancara dengan kriteria cukup berati terpenuhinya semua unsur pembelajaran sesuai dengan tuntutan Kurikulum 2013 namun tidak dilakukan secara optimal. Dalam hal ini djumpai kondisi-kondisi antara lain ketrampilan HOTs dan pemecahan masalah tidak selalu diberikan, pembelajaran tidak selalu berbantuan IT, dan penilaian proses tidak selalu dilakukan.

\section{Sedangkan transkrip wawancara terhadap responden dengan kriteria kurang dapat dilihat pada transkrip berikut.}

$P$ (Peneliti) : Apakah Anda benar-benar melaksanakan pengukuran ketercapaian indikator?

$R$ (Responden) : Ya, tapi hanya memuat tuntutan minimum yang tertuang dalam $K D$,

P: Apakah Anda mendorong siswa mencapai level berpikir tinggi (HOTS)/Problem solving

R: Tidak, khawatir siswa kesulitan memahaminya.

P: Apakah Anda dalam menyajikan materi selalu menyesuaikan dengan indicator yang dikembangkan?

R: Tidak, materi tidak perlu dituliskan secara detail karena guru dapat melihatnya dari indikator pembelajaran 
P: Apakah Anda dalam menyajikan materi selalu menggunakan lebih dari satu sumber belajar yang relevan

R: Tidak, saya hanya menggunakan satu sumber belajar yang mudah digunakan siswa

P: Apakah Anda dalam menyajikan materi selalu menggunakan teknologi informatika dan komunikasi atau jaringan internet?

R: Tidak, karena sumber dan media berbasis IT itu rumit dan menyita waktu

P: Apakah Anda dalam menyajikan materi selalu menggunakan metode/model/pendekatan yang tertulis dalam RPP?

R: Tidak, yang penting siswa lebih mudah dan cepat dalam mengusai materi pembelajaran

P: Apakah kegiatan pembelajaran Anda laksanakan sesuai RPP yang dibuat?

R: Tidak cukup sesuai, yang penting runtut dari kegiatan pendahuluan, inti, dan penutup, .

P: Apakah Anda selalu melaksanakan kegiatan saintifik/kegiatan pemecahan masalah?

R: Tidak, karena mempertimbangkan alokasi waktu dan ketuntasan kurikulum

P: Apakah Anda melakukan penilian proses pembelajaran (sesuai dengan yang tertulis dalam RPP)?

R: Tidak, menurut saya dalam kegiatan evaluasi pembelajaran adalah ketercapaian indikator pembelajaran yang dilakukan melalui tes akhir pembelajaran

Hasil wawancara pada kriteria kurang menunjukkan bahwa unsur-unsur pembelajaran sesuai tuntutan kurikulum 2013 secara umum tidak terpenuhi. Dalam hal ini dijumpai: keterampilan HOTs dan pemecahan masalah sangat jarang diberikan, materi tidak diitulis dengan detail, pembelajaran tidak berbasis IT, kegiatan pembelajaran tidak berpedoman pada RPP, dan evaluasi hanya sekedar mengukur ketercapaian indikator saja (tidak melakukan penilaian yang komprehensif).

Gambaran umum dari hasil penelitian menunjukkan bahwa guru telah mempunyai produk RPP yang baik dan lengkap sesuai ketentuan yang disyaratkan, namun RPP tersebut belum dapat diimplementasikan sepenuhnya dalam praktik pembelajaran. RPP yang disusun guru, cenderung belum menjadi panduan baginya dalam mengelola kegiatan pembelajaran. Jadi masih terdapat ketimpangan antara perencanaan dengan realisasi pelaksanaan pembelajaran, khususnya pada enam aspek penilaian yang menjadi indikator dalam penelitian ini, meliputi: perumusan indikator, penjabaran materi pelajaran, sumber dan media pembelajaran, metode/model/pendekatan pembelajaran, kegiatan pembelajaran, dan evaluasi pembelajaran.

Pada aspek perumusan indikator pencapaian kompetensi (IPK), RPP telah memuat rumusan IPK yang cukup baik, namun implementasinya hanya memenuhi kriteria kurang. IPK berfungsi mengukur tingkat kebererhasilan proses pembelajaran dikaitkan dengan tujuan pembelajaran yang diharapkan, sehingga IPK harus dirumuskan dan dikembangkan berdasarkan KD yang ada, dengan menggunakan kata kerja operasional yang dapat diamati dan diukur, mencakup sikap, pengetahuan, dan 
keterampilan. Untuk mendorong terwujudnya peningkatan kemampuan siswa, IPK diharapkan memuat kemampuan keterampilan berpikir tingkat tinggi atau higher order thinking skill (HOTS) dan pemecahan masalah. Pada penelitian ini, rumusan IPK yang disusun guru matematika umumnyaa telah dikembangkan berdasarkan KD yang ada, namun hanya ada beberapa RPP saja yang memunculkan HOTs dan pemecahan masalah. Ada banyak alasan tidak dimunculkannya rumusan IPK yang menunjukkan kemampuan HOTs dan pemecahan masalah, diantaranya ketidakyakinan guru terhadap kemampuan siswa, kekhawatiran guru terhadap alokasi waktu yang dibutuhkan, dan kesulitan guru mencari referensi materi yang relevan dengan HOTs dan pemecahan masalah. Hal ini sejalan dengan hasil penelitian Latifa (2017), bahwa para guru mampu merumuskan pernyataan obyektif yang sesuai dengan tujuan kurikulum 2013, namun mereka tidak berhasil membuat pernyataan obyektif belajar dengan unsur-unsur 'ABCD' (Audience, Behavior, Condition and Degree) yang lengkap. Para guru tampaknya mengabaikan Degree paling banyak dibandingkan dengan elemen lainnya, menyebabkan pernyataan yang dihasilkan kehilangan kriteria terukurnya. Bahkan para guru, pada saat yang sama, cenderung meninggalkan ranah afektif dan psikomotor yang juga sama pentingnya dengan ranah kognitif.

Pada aspek penjabaran materi pelajaran, RPP telah memuat substansi materi pelajaran yang dijabarkan dengan cukup baik, dan implementasinya juga telah memenuhi kriteria cukup pula. Meskipun semua RPP telah mencantumkan materi pembelajaran sesuai dengan KI dan KD yang ditetapkan, namun kualitas penjabarannya berbeda-beda. Sebagian besar RPP hanya menyajikan materi pada garis besarnya saja, penjabaran materi cenderung tidak memperhatikan tingkat kemampuan siswa, dan masih sangat sedikit RPP yang memasukkan materi berkaitan dengan kehidupan dunia nyata. Padahal penjabaran materi diperlukan untuk memberikan batasan-batasan tema atau materi pembelajaran yang diperlukan. Rumusan materi pelajaran yang terjabar dengan baik akan memudahkan guru dalam menjelaskan materi dan mencapai tujuan pembelajaran sesuai dengan indikator yang ditetapkan. Menurut Muijs \& Reynolds (2008) salah satu elemen dari pengajaran langsung yang efektif adalah pelajaran yang distrukturisasi dengan jelas. Materi pelajaran yang distrukturisasi dengan jelas akan memudahkan siswa dalam memahami isi pelajaran dan hubungannya dengan apa yang telah mereka ketahui. Dalam pelaksanaan pembelajaran, guru lebih fokus pada pemberian materi yang berorientasi pada rumusan KI dan KD, serta disesuaikan dengan kemampuan mayoritas siswa. Pemberian materi pembelajaran yang berhubungan dengan 
penerapan dalam kehidupan sehari-hari sangat jarang dilakukan, karena guru menganggap kemampuan itu hanya diminati dan dimiliki oleh sedikit siswa saja, sehingga jika harus diberikan dapat menyebabkan pembelajaran menjadi kurang efektif. Hal ini tentu bertentangan dengan dengan konsep pembelajaran konstekstual. Menurut Rusman (2013), untuk memperkuat pengalaman belajar yang dimiliki siswa diperlukan pembelajaran yang lebih banyak memberikan kesempatan kepada siswa untuk melakukan, mencoba, dan mengalami sendiri (learning to do), bukan sekedar pendengar yang pasih yang hanya menerima informasi dari guru.

Pada aspek sumber dan media pembelajaran, RPP telah mencantumkan sumber dan media pembelajaran dituliskan dengan cukup variatif, namun dalam implementasinya tidak banyak sumber dan media pembelajaran yang digunakan. Sumber dan media pembelajaran yang relevan, khususnya yang berbasis ICT (information and communication technology), perlu disiapkan dengan sebaik-baiknya agar kegiatan pembelajaran menjadi lebih menarik. Karena menurut Sundayana (2015), penggunaan media pembelajaran akan memudahkan guru dalam menyampaikan materi, dengan bantuan media yang menarik, siswa akan lebih mudah memahami materi, dan ini berdampak positif bagi prestasi belajar siswa. Menurut Muijs \& Reynolds (2008) penggunaan ICT dapat membantu siswa menyelesaikan tugas-tugas rutin dengan cepat dan otomatik, serta memudahkan siswa dalam mengakses dan menangani informasi,. Menurut Agyei \& Voogt (2012), integrasi teknologi dalam pendidikan semakin menjadi perhatian penting dalam pendidikan tidak hanya di negara maju, tetapi juga di negara berkembang. Teknologi yang digunakan secara efektif di ruang kelas memungkinkan siswa untuk menjadi inovatif sambil mengembangkan keterampilan baru dan memberi siswa informasi futuristic (Dias \& Victor, 2017) dan pembelajaran matematika konstektual menggunakan bantuan media dapat meningkatkan prestasi belajar siswa (Sidabutar, 2016). Permasalah terjadi karena terbatasnya kemampuan guru matematika dalam bidang ICT. Sehingga perlu ada dorongan internal (kemauan guru untuk meningkatkan kompetensinya) dan dorongan eksternal (pelatihan penyusunan sumber dan media pembelajaran yang diselenggarakan oleh sekolah).

Pada aspek metode/model/pendekatan pembelajaran, RPP yang disusun guru telah mencantumkan metode/model/pendekatan pembelajaran yang akan digunakan, namun metode/model/pendekatan tersebut tidak bisa diimplementasikan dengan baik. Padahal menurut Joyce, Weil, \& Calhoun (2011), cara penerapan suatu model pembelajaran akan berpengaruh besar 
terhadap kemampuan siswa menjadi para pembelajar yang handal (powerful learners). Pembelajaran yang sukses adalah pembelajaran yang mampu melibatkan siswanya dalam tugas-tugas yang sarat dengan muatan-muatan kognitif dan sosial, dan mengajari mereka bagaimana mengerjakan tugastugas tersebut secara produktif. Oleh karena itu, selain memiliki kemampuan dalam mendesain pembelajaran, guru juga dituntut mampu mengimplementasikan metode/model/pendekatan yang telah didesainnya.

Pada aspek kegiatan pembelajaran, RPP yang disusun guru telah menyajikan rumusan kegiatan pembelajaran yang dirinci dengan cukup baik. RPP telah memuat kegiatan pendahuluan, kegiatan inti, dan kegiatan penutup, namun pada kegiatan inti, sintaks model pembelajaran dan pendekatan saintifik belum dijabarkan secara rinci. Hal ini sangat mempengaruhi lemahnya implementasi RPP dalam proses pembelajaran. Guru merasa kesulitan dalam melaksanakan kegiatan pembelajaran yang sesuai dengan RPP. Kegiatan pemecahan masalah, baik secara kolaboratif maupun individual, jarang sekali bisa dilaksanakan karena orientasi pembelajaran lebih banyak bertumpu pada tercapainya target kurikulum dan indikator pembelajaran. Setidak-tidaknya ada empat alasan guru yang menyebabkan lemahnya implementasi RPP dalam proses pembelajaran antara lain karena (1) keterbatasan alokasi waktu yang tersedia, (2) banyaknya materi yang harus dituntaskan, (3) keterbatasan sumber dan media pembelajaran, dan (3) kemampuan dasar siswa yang berbeda-beda. Padahal menurut Rogers (Feist \& Feist, 2013), ilmu pengetahuan bermula dan berakhir pada pengalaman subjektif walaupun semua yang ada diantaranya harus objektif dan empiris, ilmuan (dalam hal ini siswa), harus memiliki karakteristik manusia masa depan, yaitu mereka harus didorong untuk menjadi intuitif dan kreatif, untuk terbuka pada pengalaman, untuk menerima perubahan, untuk mempunyai pandangan yang baru, dan untuk memiliki kepercayaan yang penuh atas diri mereka. Oleh karena itu, sangat penting bagi guru untuk memiliki mindset tentang kegiatan pembelajaran yang dapat mempersiapkan siswa sebagai manusia masa depan.

Pada aspek evaluasi/penilaian pembelajaran, semua RPP yang disusun guru telah memuat instrumen penilaian akhir sesuai dengan indikator yang ditetapkan, meskipun sebagian RPP tidak mencantumkan pedoman penskoran. Sebagian besar RPP juga telah melampirkan instrumen penilaian proses pembelajaran untuk penilaian sikap. Namun demikian, sebagian besar instrumen penilaian yang dibuat guru belum dikontruksi dengan baik. Hal ini sejalan dengan hasil penelitian Jaedun, Hariyanto, \& Nuryadin, (2014); Kuncara, Sujadi, \& Riyadi (2016) yang mengungkapkan bahwa guru 
dalam melaksanakan penilaian pembelajaran dalam menerapkan Kurikulum 2013 berada dalam kondisi yang tidak siap, dimana pemahaman guru yang tidak memadai tentang prinsip, prosedur, dan teknik penilaian sesuai dengan prinsip penilaian otentik. Padahal tugas guru dalam menilai pembelajaran, menurut Rusman (2013) meliputi melakukan penilaian dengan menggunakan instrumen penilaian yang telah dikembangkan, melakukan modifikasi dan penskoran, serta memberikan masukan dan tindaklanjut hasil penilaian melalui perbaikan atau pengayaan. Oleh karena itu, guru harus mampu mengkonstruksi instrumen penilaian yang tepat dan

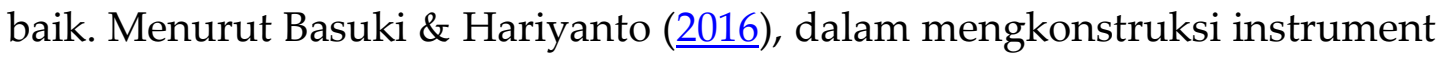
penilaian perlu diperhatikan, antara lain (1) soal dibuat sebelum memulai suatu unit pembelajaran, (2) soal perpedoman pada tujuan pembelajaran, (3) dibuat petunjuk yang jelas pada setiap bagian instrumen soal, (4) pertanyaan disusun dari sederhana menuju ke yang lebih rumit, (5) mencantumkan nilai pada bagian soal, (6) instrumen dibuat bervariasi, (7) mengelompokkan pertanyaan yang sejenis, (8) mencetak soal dengan jelas dan dapat dipahami siswa, (9) instrumen sesuai dengan kemampuan siswa, dan (10) menyediakan waktu yang mencukupi untuk siswa.

Selanjutnya dalam pelaksanaan pembelajaran, kegiatan penilaian lebih sering terbatas pada penilaian akhir pembelajaran, sedangkan penilaian proses jarang sekali dapat dilakukan. Guru merasa waktunya telah dihabiskan untuk membimbing siswa menguasai materi pelajaran, sehingga mereka merasa kesulitan melakukan penilaian proses dan penilaianpenilaian yang lain. Padahal penilaian proses sangat penting dilakukan untuk mendorong keterlibatan siswa dalam proses pembelajaran. Oleh karena itu, menurut Rusman (2013), guru perlu didorong memiliki keterampilan-keterampilan yang diperlukan untuk melaksanakan tugas penilaian pembelajaran yakni memahami metodologi penilaian pembelajaran yang meliputi eknik dan instrumen penilaian, kriteria penilaian yang baik, bentuk dan jenis tes, penskoran, statistik yang berhubungan dengan penilaian, serta program pelaksanaan remidial dan pengayaan.

Dari keseluruhan penjelasan di atas menunjukkan bahwa terdapat fenomena ketidak-konsistenan antara RPP yang dibuat guru dengan implementasinya dalam proses pembelajaran. Dalam hal ini ada dua kemungkinan yang terjadi, yaitu (1) RPP yang ditelah disusun belum sepenuhnya dijiwai oleh guru, sehingga produk RPP diragukan keotentikannya, atau (2) guru belum memiliki keterampilan praktik mengajar yang memadai. 
Apabila kemungkinan pertama yang terjadi, maka ini sejalan dengan pendapat Indriani (2017), bahwa kebanyakan RPP hanya mengadopsi dan diunduh dari internet tanpa mencermati kesesuaiannya dengan konteks kelas masing-masing. Hal ini tentu sangat mencemaskan dan harus dihindari, karena pembelajaran perlu dirancang secara sistematis untuk melibatkan intelektual dan kegiatan mental seperti motivasi, kesadaran, dan kontrol siswa secara optimal (Amin, Sukestiyarno, Waluya, \& Mariani, 2019). Dalam hal ini harus mempunyai kemampuan memahami tujuan pembelajaran, melakukan analisis pembelajaran, mengenali perilaku siswa, mengidentifikasi karakteristik siswa, merumuskan tujuan pembelajaran, mengembangkan butir-butir tes, mengembangkan materi pelajaran, menerapkan sumber-sumber pembelajaran, mengkoordinasikan segala faktor pendukung, mengembangkan dan melakukan penilaian awal terhadap RPP, merevisi pembelajaran, dan melakukan penilaian akhir terhadap RPP yang telah dibuat sebelumnya (Rusman, 2013).

Apabila kemungkinan kedua yang terjadi, maka guru perlu mengasah dan melakukan perbaikan pada praktik mengajarnya. Dalam hal ini akan sangat baik apabila guru dapat menciptakan model-model pembelajaran agar pembelajarannya dapat berjalan efektif. Menurut Joyce, Weil, \& Calhoun (2011), model-model pembelajaran hakekatnya merupakan hasil perjuangan para guru yang telah berhasil membuat jalan baru untuk melakukan penelitian. Model-model pembelajaran merupakan reportoar tentang berbagai praktek pembelajaran agar mereka dapat berinteraksi dengan para siswa dan mempertajam lingkungan/suasana saat mengajar siswa-siswanya. Kunci mendapatkan model pembelajaran yang baik adalah dengan menggunakannya sebagai perangkat penelitian - dalam hal ini perlu disediakan lingkungan-lingkungan pembelajaran, mempelajari respons siswa, dan belajar dari pengalaman.

\section{Simpulan}

Temuan umum penelitian ini menunjukkan bahwa produk RPP yang telah dibuat dan dikembangkan guru ternyata memiliki tingkat implementasi yang masih rendah dalam praktik kegiatan pembelajaran matematika SMA. Secara khusus, rendahnya tingkat implementasi jika dikaitkan dengan enam aspek supervisi diperoleh hasil: (1) meskipun perumusan indikator pencapaian kompetensi telah terjabar dengan baik, namun upaya pencapaiannya masih rendah terutama berkaitan dengan keterampilan berpikir tingkat tinggi (HOTs) dan pemecahan masalah; (3) penjabaran materi cenderung belum memperhatikan tingkat kemampuan siswa dan materi yang disajikan belum dikaitkan dengan dunia nyata; (4) sumber dan 
media pembelajaran yang dituliskan belum semuanya disiapkan dan digunakan; (5) metode/model/pendekatan pembelajaran yang dituliskan dalam RPP tidak sepenuhnya digunakan dalam praktik pembelajaran; (6) sintaks model pembelajaran dan pendekatan saintifik belum dijabarkan secara rinci baik dalam RPP maupun dalam implementasinya; (7) pada instrument evaluasi tidak mencantumkan pedoman penskoran dan belum dikontruksi dengan baik. Berkaitan dengan fenomena tersebut, disarankan beberapa hal: (1) guru perlu didorong dan dilatih dalam pengembangan RPP yang lebih mudah dilaksanakan dalam pembelajaran; (2) kegiatan pembelajaran harus mampu membiasakan siswa pada kegiatan pemecahan masalah, pengembangan HOTs dan kinerja metakognitif, serta melakukan kegiatan evaluasi yang komprehensif; (3) sekolah perlu melakukan kegiatan supervisi yang lebih intens terhadap implementasi RPP dalam praktik pembelajaran; dan (4) pemerintah perlu mendorong upaya pengembangan kurikulum yang lebih berpihak pada pengembangan kreativitas guru.

\section{Daftar Pustaka}

Agyei, D. D. \& Voogt, J. (2012). Developing Technological Pedagogical Content Knowledge in Pre-Service Mathematics Teachers Through Collaborative Design. Australasian Journal of Educational Technology, 28(4), 547-564.

Amin, I., Sukestiyarno, Waluya, B., dan Mariani, S. (2019). Pengembangan Kinerja Metakognitif Siswa untuk Meningkatkan Kemampuan Pemecahan Masalah Kolaboratif melalui Penerapan Model Pembelajaran PME. Jurnal Edukasi Matematika (EDUMAT), 10(18), 1095-1106.

Basuki, I. dan Hariyanto. (2016). Asesmen Pembelajaran (cetakan ketiga). Bandung: PT. Remaja Rosdakarya.

Cicek, V. (2013). Effective Use of Lesson Plans to Enhance Education. International Journal of Economy, Management and Social Sciences, 2(6), 334-341.

Daryanto. (2010). Media Pembelajaran. Bandung: Satu Nusa.

Dias, L. dan Victor, A. (2017). Teaching and Learning with Mobile Devices in the 21st Century Digital World: Benefits and Challenges. European Journal of Multidisciplinary Studies, 2(5), 339-334.

Duncan, G., \& Met, M. (2010). STARTALK: From Paper to Practice. College Park, MD: National Foreign Language Center at the University of Maryland.

Ejiwale, J. A. (2013). Barriers to Successful Implementation of STEM Education. Journal of Education and Learning. 7(2), 63-74.

Feist, J. \& Feist, G. J. (2013). Teori Kepribadian (Theory of Personality, 7th ed). Jakarta: Salemba Humanika.

Habib, R. B. (2017). Students Teaching Students: An Action Research Project Incorporating Active Learning at Language Classroom. Journal of Education and Human Development, 6(2), 182-199.

Holmes, K. P. \& Holmes, S. V. (2011). Hierarchy for Effective Lesson Planning: A Guide to Differentiate Instruction Through Material Selection. International Journal of Humanities and Social Science, 1(19), 144-151. 
Indriani, K. W. A. (2017). Analisis Kualitas Perancangan RPP dengan Menggunakan Kerangka Kerja ELPSA pada Focused Group Discussion di Kabupaten Sumbawa Barat. Jurnal Didaktik Matematika, 4(1), 25-34.

Jaedun, A., Hariyanto, V. L., \& Nuryadin. (2014). An Evaluation of The Implementation of Curriculum 2013 at The Building Construction Department of Vocational High School in Yogyakarta. Journal of Education, 7(1), 14-22.

John, P. D. (2006). Lesson planning and the student teacher: re-thinking the dominant model. Journal of Curriculum Studies, 38(4), 483-498.

Jones, J. (1998). Lesson planning: Towards purposeful learning and effective teaching. Encuentro. Revista de Investigación e Innovación en la clase de idiomas, 1(10), 89-98.

Joyce, B.; Weil, M.; \& Calhoun, E. (2011). Models of Teaching (Model-Model Pengajaran (edisi kedelapan). Yogyakarta: Pustaka Pelajar.

Kemdikbud. (2016). Silabus Silabus Mata Pelajaran Sekolah Menengah Atas/Madrasah Aliyah/Sekolah Menengah Kejuruan/Madrasah Aliyah Kejuruan (SMA/MA/SMK/MAK) Mata Pelajaran Matematika. Jakarta: Kemdikbud.

Kuncara, A.W., Sujadi, I., \& Riyadi. (2016). Analisis Proses Pembelajaran Matematika Berdasarkan Kurikulum 2013 pada Materi Pokok Peluang Kelas X SMA Negeri 1 Surakarta. Jurnal Elektronik Pembelajaran Matematika, 4(3), 352-365.

Latifa, I. S. (2017). The Analysis of Teachers' Lesson Plan through Behavioral Objectives Theory. Advances in Social Science, Education and Humanities Research (ASSEHR), 82(9), 6-11.

Mosothwanei, M. (2012). The Role of Senior Secondary School Mathematics Teachers in the Development of Mathematics Curriculum in Botswana. International Journal of Scientific Research in Education, 5(2), 117-129.

Muijs, D. \& Reynolds, D. (2008). Effective Teaching: Teori dan Aplikasi. Yogyakarya: Pustaka Pelajar.

Nesari, A. J. \& Heidari, M. (2014). The Important Role of Lesson Plan on Educational Achievement of Iranian EFL Teachers' Attitudes. International Journal of Foreign Language Teaching \& Research, 2(5), 27-34.

Rumahlatu, D., Huliselana, E. K. \& Takariaa, J. (2016). An Analysis of the Readiness and Implementation of 2013 Curriculum in The West Part of Seram District, Maluku Province, Indonesia. International Journal of Environmental \& Science Education, 11(12), 5662-5675.

Rusman. (2013). Model-model Pembelajaran: Mengembangkan Profesionalisme Guru (edisi kedua). Jakarta: PT. Raja Grafindo Persada.

Schunk, D. H. (2012). Learning Theories: An Education Perspective (edisi keenam). Yogyakarta: Purtaka Pelajar.

Sesiorina, S. (2014). The Analysis of Teachers' Lesson Plan in Implementing Theme-Based Instruction for Teaching English to Young Learners. Journal of English and Education, 2(1), 84-95.

Shen, J., Poppink, S., Cui, Y., \& Fan, G. (2007). Lesson Planning: A Practice of Professional Responsibility and Development. Educational Horizons, 85(4), 248-258.

Shrawder, J. H. (2006). Planning a Successful Lesson, Teaching For Success. South Lake Tahoe: CA.

Sidabutar, R. (2016). The Efforts to Improve Mathematics Learning Achievement Results of High School Students as Required by CompetencyBased Curriculum and Lesson Level-Based Curriculum. Journal of Education and Practice, 7(15), 10-15.

Sundayana, R. (2015). Media dan Peraga dalam Pembelajaran Matematika: untuk Guru, Calon Guru, Orang Tua, dan Para Pencinta Matematika. Bandung: Alfabeta. 
Wang, L., Liu, Q., Du, X., \& Liu, J. (2017). Chinese Mathematics Curriculum Reform in the 21st Century: A Review. EURASIA Journal of Mathematics Science and Technology Education, 13 (8), 5311-5326.

Zazkis, R., Liljedahl, P., \& Sinclair, N. (2009). Lesson Plays: Planning Teaching Versus Teaching Planning. For the Learning of Mathematics, 29(1), 40-47. 